\title{
The Metabolism of \\ Bacterial Nucleic Acid and of Free Components of Nucleic Acid by the Rumen Ciliate Entodinium caudatum
}

\author{
By G. S. COLEMAN \\ Department of Biochemistry, Agricultural Research Council Institute of \\ Animal Physiology, Babraham, Cambridge
}

(Accepted for publication 5 June 1968)

SUMMARY

Washed suspensions of Entodinium caudatum grown in vitro and incubated anaerobically in the presence of penicillin and neomycin for up to $6 \mathrm{hr}$ incorporated ${ }^{14} \mathrm{C}$-adenine, guanine and uracil into the cell. The ${ }^{14} \mathrm{C}$ was distributed between the cell pool of the protozoa and the nucleic acid. ${ }^{14} \mathrm{C}$-Thymine was incorporated only into the pool. There was some interconversion of the nucleic acid bases: guanine was converted to adenine and uracil to cytosine. Adenine and guanine were broken down in the medium to a mixture of hypoxanthine and xanthine, and uracil and thymine were reduced to their dihydro-derivatives. $E$. caudatum suspensions also incorporated purine and pyrimidine bases, ribose and phosphate from bacterial nucleic acid into protozoal nucleic acid and evidence was obtained that the former was degraded as far as individual nucleotides before incorporation into the latter. No evidence was obtained for the synthesis of protozoal ribose from other carbohydrates.

\section{INTRODUCTION}

Although the metabolism of proteins and amino acids by rumen micro-organisms has been extensively studied there have been very few studies on the metabolism of purine, pyrimidine and related compounds. Looper \& Stallcup (1958) showed that ammonia was released from uric acid by rumen micro-organisms and Topps \& Elliott (1965) showed that there was a positive relationship between the concentration of ruminal nucleic acid and the excretion of purine derivatives by sheep. Ellis \& Pfander (1965) stressed the importance of nucleic acid synthesis in the rumen when they showed that up to $13 \%$ of the nitrogen in the feed could be converted into nucleic acid in the rumen. Little has been done on the metabolism of nucleic acid constituents in the rumen, although the present author (Coleman, 1964) showed that bacterial adenine and guanine were incorporated into protozoal nucleic acid. The present paper extends this work. It has been found that purines and pyrimidines are interconverted and broken down to a limited extent by Entodinium caudatum.

\section{METHODS}

Source of protozoa. Entodinium caudatum was grown and inoculum cultures prepared and treated as described by Coleman (1962) except that inoculum cultures were treated each day with $15 \mathrm{mg}$. rice starch and about $10 \mathrm{mg}$. dried grass.

Preparation of protozoa for inoculation. The protozoa were present as a loose pellet 
at the bottom of the tube containing the inoculum cultures. After removal of the surface scum and most of the medium, the protozoa and remaining medium were transferred to $8 \times \mathrm{r}$ inch tubes and allowed to stand until any grass present had sunk to the bottom, leaving the protozoa in the supernatant fluid. This supernatant fluid was transferred to centrifuge tubes, the residual grass washed with salt solution $B$ (Coleman, 1960) and the washings added to the supernatant fluid. The protozoa were spun down and washed four times in salt solution B through which $95 \%(\mathrm{v} / \mathrm{v}) \mathrm{N}_{2}+$ $5 \%(\mathrm{v} / \mathrm{v}) \mathrm{CO}_{2}$ had been bubbled vigorously for $3 \mathrm{~min}$., on a bucket-head centrifuge for $20 \mathrm{sec}$. from starting; the maximum speed was equivalent to $200 \mathrm{~g}$. The protozoa were finally used as an inoculum to give a population density of $4-10 \times 10^{4}$ protozoa/ $\mathrm{ml}$. except in experiments on the constituents of the pool or metabolites in the medium where concentrations up to $10^{6}$ protozoa $/ \mathrm{ml}$. were used.

Incubation conditions for experiments on metabolism of free purines and pyrimidines.

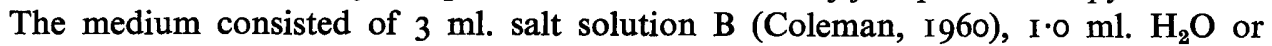
${ }^{14} \mathrm{C}$-purine or pyrimidine solution autoclaved ( $15^{\circ}$ for $20 \mathrm{~min}$.) in a $10 \mathrm{ml}$. centrifuge tube. Immediately after removal from the autoclave the following additions were made aseptically: 0. I ml. I \% L-cysteine hydrochloride (neutralized and Seitz-filtered), $0.2 \mathrm{ml}$. penicillin G solution (25,000 units $/ \mathrm{ml}$.), $0.2 \mathrm{ml}$. I \% neomycin sulphate solution and any other additions. For experiments longer than $\mathrm{I} 2 \mathrm{hr} 0.5 \mathrm{ml}$. autoclaved rumen fluid (PARF; Coleman, r962) and $0.2 \mathrm{ml}$. $1.5 \%$ rice starch suspension were also added to prolong the life of the protozoa.

Incubation conditions for engulfment of bacteria by protozoa. The medium consisted of $3 \mathrm{ml}$. salt solution B (Coleman, 1960 ) and $\mathrm{I} \cdot \mathrm{O} \mathrm{ml} . \mathrm{H}_{2} \mathrm{O}$ or purine or pyrimidine solution (if any), autoclaved ( $I I^{\circ}$ for $20 \mathrm{~min}$.) in a Io $\mathrm{ml}$. centrifuge tube. Immediately after removal from the autoclave the following additions were made aseptically: $0 \cdot 1 \mathrm{ml}$. I \% L-cysteine hydrochloride (neutralized and Seitz-filtered), $0.5 \mathrm{ml}$. suspension of ${ }^{14} \mathrm{C}$-bacteria in salt solution $\mathrm{B}$ (washed once and suspended at a concentration of $10^{9}$ to $10^{11}$ bacteria $/ \mathrm{ml}$.) and any other additions.

Under both conditions after inoculation the tubes were gassed with $95 \%(\mathrm{v} / \mathrm{v})$ $\mathrm{N}_{2}+5 \%(\mathrm{v} / \mathrm{v}) \mathrm{CO}_{2}$, sealed with a rubber bung and incubated at $39^{\circ}$. At the end of the experiment the protozoa were centrifuged down and washed twice in salt solution $\mathrm{B}$ on a bucket-head centrifuge for $30 \mathrm{sec}$. from starting (the maximum speed was equivalent to $300 \mathrm{~g}$ ). Under these conditions less than $\mathrm{I} \%$ of any free bacteria were sedimented with the protozoa. The residual bacteria were spun down from the first supernatant fluid obtained after removal of the protozoa and washed once at $2000 \mathrm{~g}$ for ro min. on an angle-head centrifuge. Samples of the supernatant fluid after removal of bacteria were placed on planchets for the estimation of ${ }^{14} \mathrm{C}$-compounds which were free in the medium.

Escherichia coli growth media. Escherichia coli was grown and maintained at $39^{\circ}$ in C medium (Roberts et al. 1955) containing $0.2 \%$ (w/v) glucose and aerated during incubation by sterile air passed in through a cottonwool-plugged Pasteur pipette. To obtain bacteria uniformly labelled with ${ }^{32} \mathrm{P}, E$. coli was grown for $\mathrm{I} 8 \mathrm{hr}$ under the same conditions in a medium that contained (per litre): $0^{\circ} \mathrm{I}$ M- $\beta \beta^{\prime}$-dimethylglutaric acid $+\mathrm{NaOH}$ buffer (pH 7.0) $300 \mathrm{ml}$; $\mathrm{NaCl}, 7 \mathrm{~g}$; $\mathrm{NH}_{4} \mathrm{Cl}, 2$ g.; ${ }^{32} \mathrm{P}-\mathrm{KH}_{2} \mathrm{PO}_{4}(2500 \mu \mathrm{c}$. g.), $0 \cdot 2$ g.; glucose, 2 g. It was not possible to obtain $E$. coli specifically labelled with one purine or pyrimidine, since some interchange of carbon between adenine and guanine and between uracil and cytosine always occurred. In an attempt to decrease 
this and to obtain bacteria principally labelled with one ${ }^{14} \mathrm{C}$-purine or pyrimidine, the bacteria were grown in $\mathrm{C}$ medium $+0.2 \%$ glucose $+0.05 \mu \mathrm{C}{ }^{14} \mathrm{C}$-adenine, guanine or uracil/ml. in the presence of a saturated solution of the ${ }^{12} \mathrm{C}$-guanine, adenine or cytosine respectively. The labelling patterns obtained are given in Results.

Protozoal counts. The number of protozoa was estimated by the method of Coleman (1958). Only those protozoa which showed no signs of disintegration were counted.

Estimation of ${ }^{14} \mathrm{C}$ and ${ }^{32} \mathrm{P} .{ }^{14} \mathrm{C}$ or ${ }^{32} \mathrm{P}$ in whole protozoa was estimated by washing the organisms with water on to an aluminium planchet of area $4.7 \mathrm{~cm} .{ }^{2}$ carrying a disc of lens tissue. The sample was spread by one drop of cetyltrimethylammonium bromide solution $(5 \mathrm{mg}$. $/ \mathrm{ml}$.) and fixed by one drop of polyvinyl alcohol $(2 \mathrm{mg} . / \mathrm{ml}$.). The disc was dried at $40^{\circ}$ and the ${ }^{14} \mathrm{C}$ estimated by means of an automatic flow counter (NuclearChicago Corp.) with an efficiency of about $20 \%$. Over 1000 counts at a rate greater than three times background (usually greater than ten times) were recorded for all fractions. Determinations were made with less than $0.5 \mathrm{mg}$. material $/ \mathrm{cm} .{ }^{2}$ of disc. The amount of purine or pyrimidine incorporated from the medium by protozoa was calculated from the known specific activity (usually 0.005 to $0.2 \mu \mathrm{c} / \mu \mathrm{mole}$ ) of the purine or pyrimidine added initially. To determine the relative ${ }^{14} \mathrm{C}$ contents of spots on a chromatogram a thin mica end-window GM tube was placed directly on the spot, the position of which had been determined by radioautography.

To estimate ${ }^{14} \mathrm{C}$ and ${ }^{32} \mathrm{P}$ in the presence of each other planchets were counted both normally and when covered with a disc of used X-ray film. This film was opaque to the radiation from ${ }^{14} \mathrm{C}$ but decreased the count obtained from ${ }^{32} \mathrm{P}$ by only $2 \mathrm{I} \%$ when used under conditions for planchet counting and by only $10 \%$ when the material was on a chromatogram and the used film was placed directly between the GM tube and the paper. Then, if $x=$ normal unshielded count and $y=$ shielded count, ${ }^{32} \mathrm{P}$ count $=(\mathrm{I} \cdot 27$ or $\mathrm{I} \cdot \mathrm{II}) y$ and ${ }^{{ }^{4}} \mathrm{C}$ count $=x-\left(\mathrm{I} \cdot 27\right.$ or $\left.\mathrm{I}^{\mathrm{I}} \mathrm{II}\right) y$. In those experiments where the ${ }^{14} \mathrm{C} /{ }^{32} \mathrm{P}$ ratio was low, the ${ }^{14} \mathrm{C}$ count was confirmed by redetermination after the ${ }^{32} \mathrm{P}$ had decayed to approximately I \% of its original value.

Fractionation of organisms. The protozoa after harvesting, washing as described above and resuspension in $2 \mathrm{ml}$. water in a $5 \times \frac{1}{2}$ inch thin-walled test tube were broken by immersion of the tube to the level of the meniscus in the tube in a $80 \mathrm{kcyc} / \mathrm{sec}$. $40 \mathrm{~W}$ ultrasonic cleaning bath (KG 80/1, manufactured by Kerry's of Chester Hall Lane, Basildon, Essex) for $15 \mathrm{sec}$. The homogenate was then centrifuged at $7000 \mathrm{~g}$ for $20 \mathrm{~min}$. The supernatant liquid from this centrifugation is hereafter referred to as the 'broken cell supernatant fluid' and the pellet after washing once in water as the 'broken cell pellet'. This latter fraction contained all the viable bacteria in the homogenate.

These two fractions were further fractionated by a method based on that of Roberts et al. (1955). The fraction was treated with $5 \%$ trichloroacetic acid (TCA) and allowed to stand at $4^{\circ}$ for $30 \mathrm{~min}$. The precipitate was centrifuged down and washed once in $5 \%$ TCA. The supernatant fluid and the washing formed the 'cold TCA-soluble fraction'. The precipitate was then extracted twice with $5 \% \mathrm{TCA}$ at $100^{\circ}$ for $20 \mathrm{~min}$. The supernatant fluids formed the 'hot TCA-soluble or nucleic acid fraction'. The residue was dissolved in $0.1 \mathrm{~N}-\mathrm{NaOH}$ and formed the 'residual protein fraction'. The TCA was removed from fractions by washing three times with ether before plating out for the estimation of ${ }^{14} \mathrm{C}$.

The hot TCA soluble fraction, after ether extraction, was evaporated to dryness in 
a desiccator and further hydrolysed by one of the following methods. To liberate the free purines and pyrimidines the fraction was treated with $72 \% \mathrm{HClO}_{4}$ for I $\mathrm{hr}$ at $100^{\circ}$ (Wyatt, 195I) and the $\mathrm{HClO}_{4}$ diluted with an equal volume of water before application to paper for chromatography. To liberate adenine and guanine and the pyrimidine nucleotides the fraction was treated with $\mathrm{N}-\mathrm{HCl}$ for $\mathrm{I} \mathrm{hr}$ at $100^{\circ}$ (Smith \& Markham, 1950). To liberate the purine and pyrimidine ribonucleotides the pellet after treatment with cold TCA only was dissolved in $0.3 \mathrm{~N}-\mathrm{KOH}$ and allowed to stand for $18 \mathrm{hr}$ at $37^{\circ}$ (Davidson \& Smellie, 1952). The DNA, protein and potassium were then precipitated by the addition of $\mathrm{HClO}_{4}$.

Paper chromatography. The following solvents were used: A, sec.-butanol + formic acid + water $(70+10+20$, by vol.); B, isopropanol $+\mathrm{HCl}$ (sp.gr. $\mathrm{I} \cdot 18)+\mathrm{H}_{2} \mathrm{O}$ $\left(65+\mathrm{I} 7+\mathrm{I} 8\right.$, by vol.); C, $n$-butanol saturated with $\mathrm{I} \cdot 5 \mathrm{~N}-\mathrm{NH}_{4} \mathrm{OH} ; \mathrm{D}, n$-propanol + ethyl acetate $+\mathrm{H}_{2} \mathrm{O}\left(24+\mathrm{r}_{3}+7\right.$, by vol. $) ; \mathrm{E}$, sec.-butanol + tert.-butanol $+\mathrm{H}_{2} \mathrm{O}$ $\left(5+\mathrm{I}+5 \cdot 6\right.$, by vol., upper phase); $\mathrm{F}, n$-butanol $+\mathrm{H}_{2} \mathrm{O}+$ formic acid $(77+\mathrm{I} 3+\mathrm{ro}$, by vol.); $\mathrm{G}$, acetone $+25 \%$ TCA ( $75+25$, by vol.).

Chemicals. Dihydrouracil and dihydrothymine were supplied by Sigma London Chemical Co. Ltd. (I2 Lettice Street, London, S.W. 6). ${ }^{14} \mathrm{C}$ and ${ }^{32} \mathrm{P}$ compounds were supplied by the Radiochemical Centre, Amersham, Buckinghamshire. The specific activities of the ${ }^{14} \mathrm{C}$-compounds as supplied were, in $\mu \mathrm{c} / \mathrm{mg}$.: $\left[8-{ }^{14} \mathrm{C}\right]$ adenine, 162 ; $\left[8-{ }^{14} \mathrm{C}\right]$ guanine, $7 \mathrm{I} ;\left[\mathrm{I}^{-14} \mathrm{C}\right] \mathrm{D}-\mathrm{ribose}, 55 ;\left[{ }^{-14} \mathrm{C}\right]$ thymine, $319 ;\left[2^{-14} \mathrm{C}\right]$ uracil, $36 \mathrm{I}$; [U-14C]uridine, 1870 .

\section{RESULTS}

\section{The metabolism of free purines and pyrimidines}

Washed suspensions of Entodinium caudatum prepared from growing cultures and incubated anaerobically in the presence of penicillin and neomycin incorporated ${ }^{14} \mathrm{C}$ from $\left[8-{ }^{14} \mathrm{C}\right]$ adenine, $\left[8-{ }^{14} \mathrm{C}\right]$ guanine and $\left[2-{ }^{14} \mathrm{C}\right]$ uracil progressively over $6 \mathrm{hr}$. In contrast, incorporation of ${ }^{14} \mathrm{C}$ from $\left[2^{-14} \mathrm{C}\right]$ thymine reached a maximum after $5 \mathrm{~min}$. and remained unchanged for the next $6 \mathrm{hr}$. (Fig. I). Incubation of the protozoa with $0.01 \mathrm{M}^{-12} \mathrm{C}$-thymine for 0 to $240 \mathrm{~min}$. before the addition of $0.05 \mu \mathrm{C}(0.012 \mu$ mole)/ $\mathrm{ml} .{ }^{14} \mathrm{C}$-thymine did not alter the rate of incorporation of ${ }^{14} \mathrm{C}$. This suggested that although the intracellular compound derived from thymine was not removable by washing, it rapidly 'exchanged' with thymine in the medium on incubation of the protozoa at $39^{\circ}$. After incubation for $\mathrm{I} \mathrm{hr}$ in the presence of each compound at $0.00 \mathrm{I} \mathrm{M}$ the incorporation was $0.0057,0.0014,0.00088$ and $0.00 \mathrm{I} \mathrm{I} \mu \mathrm{g} . / 10^{6}$ protozoa for adenine, guanine, thymine and uracil, respectively.

Effect of purine and pyrimidine concentration. Figure 2 is a reciprocal plot of the effect of substrate concentration on the incorporation of ${ }^{14} \mathrm{C}$ from ${ }^{14} \mathrm{C}$-uracil and ${ }^{14} \mathrm{C}$-thymine into washed protozoa. There was a sharp break in the curve for uracil incorporation at $0.007 \mathrm{M}$, whereas the curve for thymine showed no obvious discontinuity. However, as these pyrimidines are not very soluble and the length of the left-hand part of the curves therefore limited, it might not be possible to detect a discontinuity especially if the slopes before and after the break were similar. The curve for adenine incorporation showed a break at $0.0064 \mathrm{M}$. Unfortunately it was not possible to measure the incorporation of ${ }^{14} \mathrm{C}$-guanine at concentrations above $1 \mathrm{O}^{-3} \mathrm{M}$ because of its insolubility.

As was shown for the incorporation of amino acids (Coleman, 1967a), it is possible 
to extrapolate the right-hand part of the uracil and adenine curves to the ordinate and measure the maximum rate at infinite substrate concentration. The maximum rates calculated in this way were 0.0103 and $0.031 \mu \mathrm{moles} / \mathrm{hr} / 10^{6}$ protozoa for uracil and adenine, respectively. The left-hand part of the curves passes near to or through the origin and over this part of the curve the proportion of the original purine or pyrimidine that was incorporated was independent of its concentration. For the reasons given previously (Coleman, 1967 a) these results are interpreted as showing that at all concentrations the uracil and adenine passed into the cell by a passive process, but that at low concentrations, below the break, there was an additional uptake which might have been dependent on metabolic processes. The result with thymine suggests that if there was an 'active' uptake it was small compared with the passive even at low concentrations.

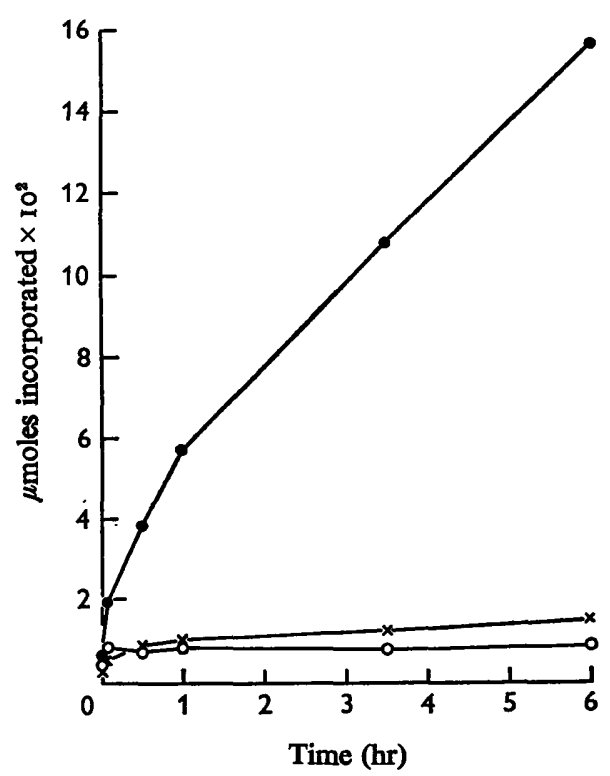

Fig. I

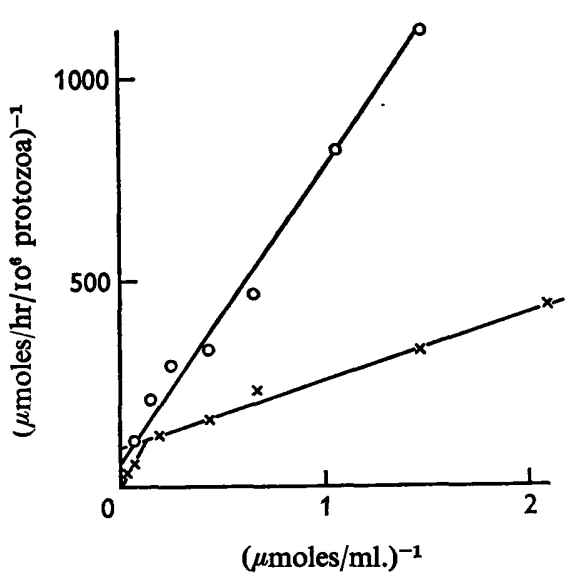

Fig. 2

Fig. I. Incorporation of $5 \times 10^{-4} \mathrm{M}-\left[8-{ }^{14} \mathrm{C}\right]$ adenine $\left({ }_{-}-0\right),\left[2-{ }^{14} \mathrm{C}\right]$ uracil $(x-\times)$ or [2-14 C] thymine $(\mathrm{O}-\mathrm{O})$ by $9.4 \times 10^{5}$ Entodinium caudatum incubated anaerobically in the presence of 1000 units penicillin $+400 \mu \mathrm{g}$. neomycin sulphate $/ \mathrm{ml}$.

Fig. 2. Effect of substrate concentration on the incorporation of $\left[2-{ }^{14} \mathrm{C}\right]$ uracil $(x-x)$ and [2-14 C]thymine $(\mathrm{O}-\mathrm{O})$ by $1.04 \times 10^{6}$ Entodinium caudatum in the presence of 1000 units penicillin $+400 \mu \mathrm{g}$. neomycin sulphate/ml.

Effect of salt concentration. Within the limits that the protozoa would tolerate without dying, alteration in the salt concentration by substitution of salt solution $B$ by water or double-strength salt solution B had little effect on the rate of uptake of adenine, uracil or thymine. In this respect these compounds were similar to group I amino acids (Coleman, 1967a).

Effect of inhibitors on incorporation. If the incorporation of uracil and adenine consisted of an 'active' and a passive process, then the passive part should be extendable by the inhibition of the 'active' process. In an attempt to find a suitable inhibitor the effect of various pyrimidines and pyrimidine analogues on the incorporation of 
${ }^{14} \mathrm{C}$-uracil was examined. None of the substances tested abolished the discontinuity in the curves but 2-thiouracil, thymine (Fig. 2) and cytosine (all at $0.0 \mathrm{I}$ M) decreased the total incorporation by 43,48 and I I \%, respectively, at an external uracil concentration of $0.00067 \mathrm{M}$. None of these compounds inhibited the passive incorporation of uracil. The incorporation of ${ }^{14} \mathrm{C}$ from ${ }^{14} \mathrm{C}$-thymine after incubation for $5 \mathrm{~min}$. was decreased $20 \%$ by $0.01 \mathrm{M}$-uracil, $16 \%$ by $0.0 \mathrm{I}$ M-cytosine and $22 \%$ by 4 -methyl2-thiouracil (0.0I M), suggesting that as with ${ }^{14} \mathrm{C}$-uracil there was some specific 'active' uptake.

\section{Table I. Distribution of ${ }^{14} \mathrm{C}$ in the organism after the incorporation of purines or pyrimidines by Entodinium caudatum}

\begin{tabular}{|c|c|c|c|c|}
\hline \multirow[t]{2}{*}{${ }^{14} \mathrm{C}$-compound incorporated } & $\begin{array}{l}{\left[8-{ }^{14} \mathrm{C}\right]-} \\
\text { adenine }\end{array}$ & $\begin{array}{l}{\left[8-{ }^{14} \mathrm{C}\right]-} \\
\text { guanine }\end{array}$ & $\begin{array}{c}{\left[2-{ }^{14} \mathrm{Cl}-\right.} \\
\text { uracil }\end{array}$ & $\begin{array}{l}{\left[2-{ }^{14} \mathrm{C}\right]-} \\
\text { thymine }\end{array}$ \\
\hline & \multicolumn{4}{|c|}{ Incorporation in whole protozoa } \\
\hline \multicolumn{5}{|l|}{ Broken-cell supernatant fluid } \\
\hline Cold trichloroacetic acid-soluble fraction & 85 & 59 & 53 & 85 \\
\hline Nucleic acid & II & 13 & 4I & 2 \\
\hline Residual protein & 0.3 & 0.3 & 0.6 & 0.4 \\
\hline \multicolumn{5}{|l|}{ Broken-cell pellet } \\
\hline Cold trichloroacetic acid-soluble fraction & - & 24 & - & - \\
\hline $\begin{array}{l}\text { Nucleic acid } \\
\text { Residual protein }\end{array}$ & 二 & $\begin{array}{l}4 \\
0 \cdot 2\end{array}$ & Z & $\bar{z}$ \\
\hline
\end{tabular}

Intracellular products of metabolism. Table I shows the distribution in the major cell fractions of ${ }^{14} \mathrm{C}$ derived from the metabolism of $\left[8-{ }^{14} \mathrm{C}\right]$ adenine, $\left[8^{-14} \mathrm{C}\right]$ guanine, $\left[2-{ }^{14} \mathrm{C}\right]$ uracil and $\left[2-{ }^{14} \mathrm{C}\right]$ thymine by Entodinium caudatum. With the exception of guanine, most of the ${ }^{14} \mathrm{C}$ was present in the cold TCA soluble fraction of the broken cell supernatant fluid, i.e. the cell pool, with little in the residual protein or in the broken cell pellet. The distribution of ${ }^{14} \mathrm{C}$ in the nucleic acid bases showed that there was some interconversion between the purines and between the pyrimidines. After an incubation with ${ }^{14} \mathrm{C}$-guanine, $84 \%$ of the nucleic acid- ${ }^{14} \mathrm{C}$ was present as guanine and I $6 \%$ as adenine. In contrast, after an incubation with ${ }^{14} \mathrm{C}$-adenine $96 \%$ of the nucleic acid $-{ }^{14} \mathrm{C}$ was present as adenine and only $4 \%$ as guanine. With ${ }^{14} \mathrm{C}$-uracil or uridine 30 to $35 \%$ of the pyrimidine ${ }^{14} \mathrm{C}$ was in cytosine and the remainder was in uracil. There was little incorporation of ${ }^{14} \mathrm{C}$-thymine into nucleic acid and the distribution of the ${ }^{14} \mathrm{C}$ was not investigated.

The constituents of the protozoal pool. The ${ }^{14} \mathrm{C}$-labelled compounds in the cold TCAsoluble fraction of the broken cell supernatant fluid of protozoa that had incorporated ${ }^{14} \mathrm{C}$ from tracer quantities of ${ }^{14} \mathrm{C}$-purines or pyrimidines are given below.

$\left[8-{ }^{14} \mathrm{C}\right]$ Adenine. The ${ }^{14} \mathrm{C}$-compounds were separated initially into three spots by chromatography in solvent $\mathbf{C}$. These spots were then eluted and chromatographed in the same solvent, when the two spots which had moved farthest were found to break up into two spots each. Of these five compounds, three were broken down to ${ }^{14} \mathrm{C}$ - 
adenine on hydrolysis in $\mathrm{N}-\mathrm{HCl}$ for $\mathrm{I} \mathrm{hr}$ at $100^{\circ}$ and were subsequently identified as adenine, adenosine and (probably) adenylic acid. This last compound was shown not to be adenosine diphosphate or adenosine triphosphate by chromatography in solvent G. The compounds which were not hydrolysable to adenine were xanthine and hypoxanthine. The proportions of the five compounds were very variable from experiment to experiment, but the adenosine was usually only a minor component.

$\left[8{ }^{14} \mathrm{C}\right]$ Guanine. $60 \%$ xanthine, $25 \%$ guanine and $15 \%$ adenine.

$\left[2-{ }^{14} \mathrm{C}\right]$ Uracil. $85 \%$ dihydrouracil and $15 \%$ uracil.

$\left[2{ }^{14} \mathrm{C}\right]$ Thymine. Dihydrothymine; little or no thymine.

Extracellular products of metabolism. The results quoted in this section were obtained with protozoa which had been incubated with $0.001 \mathrm{M}$ to $0.005 \mathrm{M}_{-}{ }^{14} \mathrm{C}$-purine or pyrimidine for up to 4 days in the presence of penicillin + neomycin + autoclaved rumen fluid and rice starch grains. In the absence of these latter two materials the protozoa lived only for $36 \mathrm{hr}$.

$\left[8-{ }^{14} \mathrm{C}\right]$ Adenine. To identify the products of adenine metabolism, the culture supernatant fluid was treated with Zeo Karb $225\left(\mathrm{H}^{+}\right)$which removed most of the ${ }^{14} \mathrm{C}$ from the medium. The resin was then washed and the ${ }^{14} \mathrm{C}$-labelled compounds eluted with $\mathrm{N}-\mathrm{NH}_{4} \mathrm{OH}$. The eluate was evaporated to dryness and the residue chromatographed in solvent $\mathrm{C}$ on acid-washed paper. The three ${ }^{14} \mathrm{C}$-labelled spots that were obtained as the result of this procedure were eluted and their nature determined: (a) by chromatography in solvents $\mathrm{A}$ to $\mathrm{F}$ next to marker compounds; (b) by the 'fingerprint' method of Roberts et al. (1955) as described by Coleman (1967a); (c) in experiments in which $0.005 \mathrm{M}$-adenine was metabolized, by determination of the ultraviolet (u.v.) spectrum by the use of a Unicam SP 700 spectrophotometer (Unicam Instruments Ltd., Cambridge) and comparison with those of known compounds. On the basis of these tests the three compounds were identified as the adenine added initially, xanthine and hypoxanthine. Figure 3 shows a time course for the formation of the latter two compounds and although they were both formed initially at the same rate it seems probable on theoretical grounds that the hypoxanthine was formed first and then oxidized to xanthine. No evidence was obtained of further oxidation to uric acid.

$\left[8-{ }^{14} \mathrm{C}\right]$ Guanine. On incubation of guanine with Entodinium caudatum in the presence of penicillin + neomycin it was converted initially quantitatively to xanthine, but subsequently up to $10 \%$ of the guanine-carbon appeared as hypoxanthine. The identity of these compounds was determined as described above. After incubation up to 3 days a variable amount $\left(25\right.$ to $75 \%$ ) of the guanine- $C_{(8)}$ was converted to a compound that was volatile on the addition of acid and which was not completely retained on a planchet by the addition of $\mathrm{NaOH}$. This compound, which might have been $\mathrm{CO}_{2}$, was not characterized further, since its failure to appear except after prolonged incubation suggested that it might be the result of bacterial metabolism.

$\left[2-{ }^{14} \mathrm{C}\right]$ Uracil. Direct chromatography of the culture supernatant fluid in solvent $\mathrm{C}$ showed that $5 \mu$ moles uracil was converted in $20 \mathrm{hr}$ by $5 \times 10^{6}$ protozoa almost quantitatively into another compound which moved faster in this solvent system $\left(\boldsymbol{R}_{F}\right.$ relative to that of uracil, $\mathrm{I} \cdot 3$ ) and which had little absorption in the u.v. as determined on the paper by the method of Markham \& Smith (1949). After elution of the unknown material it was found to have little absorption above $250 \mathrm{~m} \mu$. Of the common degradation products of pyrimidines (Schmidt, 1955) in which the ring remained intact only 
dihydrouracil fulfilled this criterion and the unknown compound was tentatively identified as dihydrouracil by chromatography in solvents $A$ to $F$ in which it ran with the same $R_{F}$ as marker dihydrouracil. This was identified on the paper by spraying with $0.5 \mathrm{~N}-\mathrm{NaOH}$, allowing the paper to dry for I $\mathrm{hr}$ and then spraying with $0.06 \mathrm{~N}-p$ dimethyl-aminobenzaldehyde in $\mathrm{N}-\mathrm{HCl}$ when the dihydrouracil appeared as a yellow spot (Campbell, 1957). Treatment of the dihydrouracil with $\mathrm{NaOH}$ converted it into

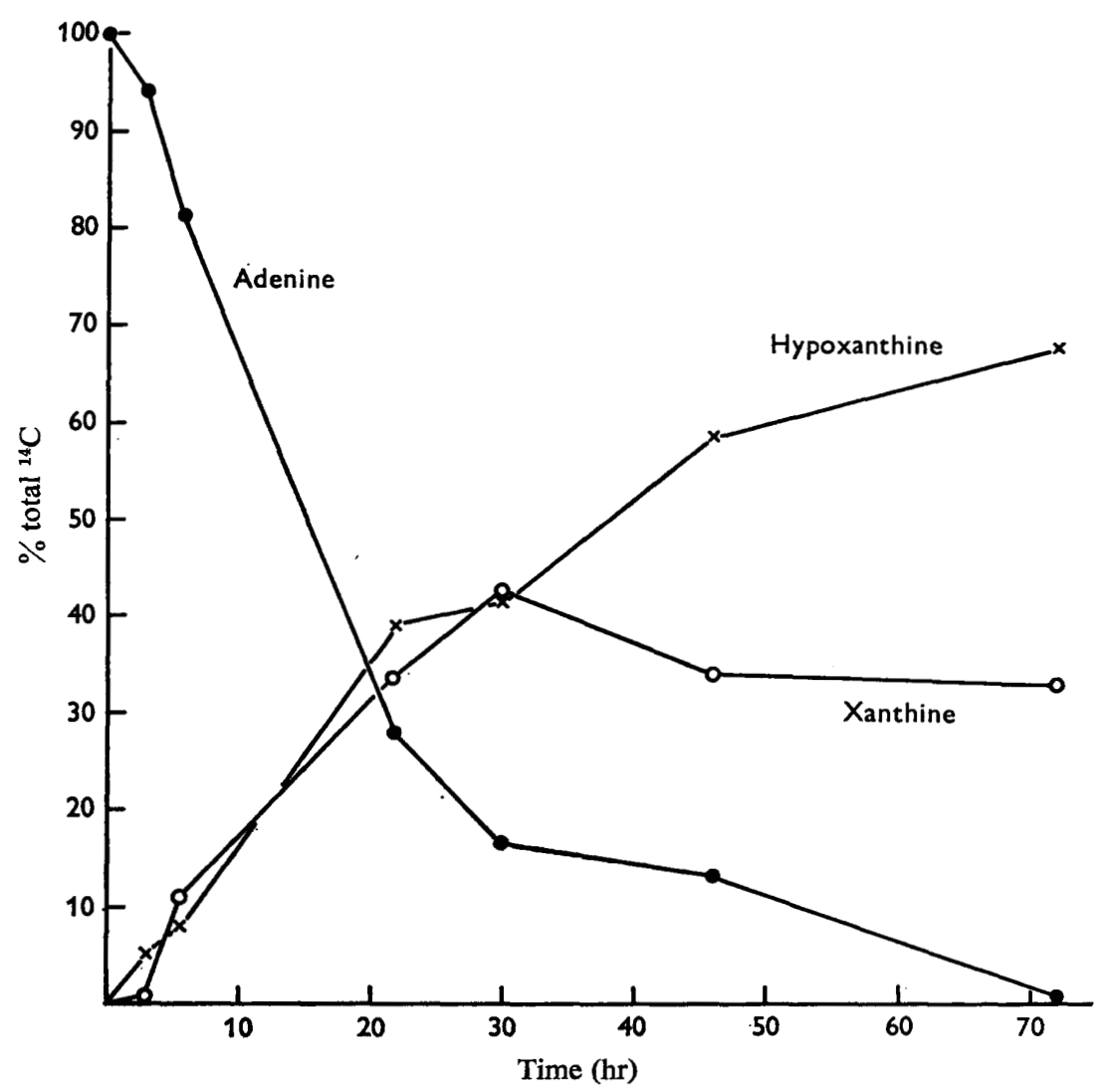

Fig. 3. Metabolism of $10^{-3} \mathrm{M}-\left[8-{ }^{14} \mathrm{C}\right]$ adenine by Entodinium caudatum incubated anaerobically in the presence of 1000 units penicillin $+400 \mu \mathrm{g}$. neomycin sulphate $/ \mathrm{ml}$. The supernatant fluid after removal of the protozoa was chromatographed in solvent $C$, the ${ }^{14} \mathrm{C}$ spots detected by radioautography and the amount of ${ }^{14} \mathrm{C}$ present in each measured directly on the paper.

$\beta$-ureidopropionic acid and treatment of the unknown material with $\mathrm{NaOH}$ produced a compound which had similar chromatographic properties to $\beta$-ureidopropionic acid in solvents $\mathrm{A}$ to $\mathrm{F}$. The identity of dihydrouracil and $\beta$-ureidopropionic acid were confirmed by the 'fingerprint' method. No evidence was obtained of any further metabolism of the dihydrouracil.

[2-14C]Thymine. Thymine (5 $\mu$ moles) was metabolized almost quantitatively to dihydrothymine by $5 \times 10^{6}$ protozoa in $20 \mathrm{hr}$, but this was not metabolized further as determined by chromatography in solvent $\mathrm{C}$. Dihydrothymine was identified in the same way as dihydrouracil, utilizing the property that, in the presence of $\mathrm{NaOH}$, 
dihydrothymine was broken down to $\beta$-ureidoisobutyric acid. The initial rate of formation of dihydrothymine was $0.55 \mu$ mole/hr (i.e. II \% of the thymine was metabolized each hour) and this was constant for the first $6 \mathrm{hr}$. If it be assumed that thymine must enter the protozoa before it can be metabolized then $1 \mathrm{I} \times 10^{4} \mu^{3}$ of medium must pass into each protozoon $/ \mathrm{hr}$.

\section{Permeability of Entodinium caudatum to purines and pyrimidines}

The permeability of Entodinium caudatum to purines and pyrimidines was determined as described previously for amino acids (Coleman, 1967a); 40 to $50 \%$ of a packed cell pad were found to be impermeable to adenine, guanine, uracil or thymine. As $15 \%$ of the liquid in a packed cell pad was probably extracellular (Coleman, 1967a) 35 to $45 \%$ of a protozoon must be permeable to these compounds in 2 to $5 \mathrm{~min}$. at room temperature. With ${ }^{14} \mathrm{C}$-thymine only $7 \%$ of the ${ }^{14} \mathrm{C}$ inside the protozoa could not be removed by washing and after $5 \mathrm{~min}$. incubation at $39^{\circ}$ when the incorporation had reached a maximum (Fig. I) this had increased to only 12 to $14 \%$. Since the volume of each protozoon was $4.7 \times 10^{4} \mu^{3}$ (Coleman, 1967a) and since approximately $50 \%$ of this was penetrable by thymine and other low molecular weight compounds (Coleman, $1967 a$ ) it is suggested that a volume of $2.3 \times 10^{4} \mu^{3}$ inside each protozoon was freely permeable to the medium and any solutes dissolved in it. However, it is possible that the various organic solutes tested could exchange rapidly with ${ }^{12} \mathrm{C}$-compounds inside the cell and under these conditions the thymine penetrable volume would be greater than the volume freely available to the medium. If it be assumed that the thymine and fluid penetrable volumes are the same then, since all the thymine in $\mathrm{II} \times \mathrm{IO}^{4} \mu^{3}$ of medium is reduced in $\mathrm{I} \mathrm{hr}$, the medium inside each protozoon must change 4.3 times each $\mathrm{hr}$, i.e. all the thymine in a $10^{-3} \mathrm{M}$ solution is reduced during $14 \mathrm{~min}$. inside each protozoon. If to be reduced the thymine had to penetrate into that 6 to $7 \%$ of the cell volume where it could not be removed by washing at room temperature, this time would be decreased to about $2 \mathrm{~min}$. Although the reduction of thymine is one of the most rapid reactions carried out by Entodinium caudatum on a soluble compound, both these times are long compared with that of $15 \mathrm{sec}$. for the removal of bacteria from the medium (Coleman, 1964).

\section{Metabolism of the nucleic acid constituents of Escherichia coli}

Unfortunately it was not possible to prepare Escherichia coli labelled in its nucleic acid with a single ${ }^{14} \mathrm{C}$-purine or pyrimidine. Growth of $E$. coli on a glucose + ammonia + salts medium $+\left[8-{ }^{14} \mathrm{C}\right]$ adenine in the presence of a saturated solution of ${ }^{12} \mathrm{C}$-guanine produced bacteria which contained $62 \%{ }^{14} \mathrm{C}$-adenine and $38 \%{ }^{14} \mathrm{C}$-guanine in their nucleic acid. The corresponding results for growth on $\left[8-{ }^{14} \mathrm{C}\right]$ guanine in the presence of a saturated solution of ${ }^{12} \mathrm{C}$-adenine were $75 \%{ }^{14} \mathrm{C}$-guanine and $25 \%{ }^{14} \mathrm{C}$-adenine; and for growth on [2-14 $\mathrm{C}]$ uracil in the presence of a saturated solution of cytosine and $0.01 \mathrm{M}$-L-aspartic acid were $58 \%{ }^{14} \mathrm{C}$-cytosine and $42 \%{ }^{14} \mathrm{C}$-uracil. Under all these conditions about $90 \%$ of the ${ }^{14} \mathrm{C}$ was in the bacterial nucleic acid. ${ }^{14} \mathrm{C}$-Thymine was very poorly incorporated by growing $E$. coli. No experiments were made about the metabolism of ${ }^{14} \mathrm{C}$-thymine-labelled bacteria.

Table 2 shows the distribution of ${ }^{14} \mathrm{C}$ inside the protozoa after the engulfment of Escherichia coli labelled principally in the nucleic acid with ${ }^{14} \mathrm{C}$-cytosine and ${ }^{14} \mathrm{C}$-uracil. About $70 \%$ of the ${ }^{14} \mathrm{C}$ was released into the medium and of that in the cell 65 to $70 \%$ 
was present in the nucleic acid as cytosine and uracil. However the cytosine: uracil ratio was 0.77 in the protozoa as compared with $\mathrm{I} \cdot 35$ in the original bacteria. This suggests that there was a preferential utilization of uracil, or a net conversion of cytosine to uracil, by the protozoa. The addition to the medium of ${ }^{12} \mathrm{C}$-uracil or ${ }^{12} \mathrm{C}$-cytosine decreased the incorporation of ${ }^{14} \mathrm{C}$ into whole protozoa by 50 or $35 \%$, into the cytosine of the protozoal nucleic acid by 47 or $44 \%$ and into the uracil of the protozoal nucleic acid by 72 or $53 \%$, respectively. This shows that although both pyrimidines inhibited the incorporation of uracil and cytosine, the inhibition was greatest by the ${ }^{12} \mathrm{C}$-form of the ${ }^{14} \mathrm{C}$-compound incorporated. Compared with ${ }^{12} \mathrm{C}$ uracil, ${ }^{12} \mathrm{C}$-uridine and ${ }^{12} \mathrm{C}$-uridine $5^{\prime}$-monophosphate were more effective competitors but had similar differential effects on the incorporation of ${ }^{14} \mathrm{C}$-uracil and ${ }^{14} \mathrm{C}$-cytosine from bacterial into protozoal nucleic acid. The nature of the ${ }^{14} \mathrm{C}$-compounds in the cell pool was not determined.

\title{
Table 2. The metabolism of ${ }^{14} \mathrm{C}$-uracil and ${ }^{14} \mathrm{C}$-cytosine labelled Escherichia coli by Entodinium caudatum
}

\begin{abstract}
Entodinium caudatum was incubated anaerobically in the presence of Escherichia coli labelled with $\left[2-{ }^{14} \mathrm{C}\right]$ uracil and $\left[2-{ }^{14} \mathrm{C}\right]$ cytosine $(34,500$ counts $/ \mathrm{min}$.) in the presence or absence of the ${ }^{12} \mathrm{C}$-compounds shown at $0.01 \mathrm{M}$. After incubation for $18 \mathrm{hr}$ the washed protozoa were broken by ultrasonic treatment and the supernatant fluid and pellet fractions separated by centrifugation.
\end{abstract}

\begin{tabular}{|c|c|c|c|c|c|c|}
\hline \multirow[t]{2}{*}{ 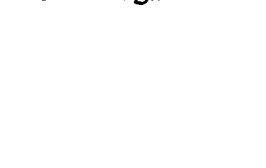 } & \multicolumn{6}{|c|}{${ }^{12} \mathrm{C}$ compounds added } \\
\hline & None & Uracil & Cytosine & Uridine & $\begin{array}{c}\text { Uridine } 5^{\prime} \\
\text { mono- } \\
\text { phosphate }\end{array}$ & $\begin{array}{l}\text { Initial } \\
E . \text { coli }\end{array}$ \\
\hline & \multicolumn{6}{|c|}{ Radioactivity (counts/min.) } \\
\hline Medium & 23,600 & 26,600 & 26,300 & 27,600 & 26,600 & - \\
\hline $\begin{array}{l}\text { Broken protozoal } \\
\text { supernatant fluid }\end{array}$ & 3,320 & 1,660 & $\mathbf{I}, 940$ & $\mathbf{I , 2 2 0}$ & I,100 & - \\
\hline $\begin{array}{l}\text { Broken protozoal } \\
\text { pellet }\end{array}$ & 300 & IIO & 400 & 250 & 200 & 一 \\
\hline \multicolumn{7}{|c|}{ Fractionation of broken protozoal supernatant fluid } \\
\hline $\begin{array}{l}\text { Cold trichloroacetic } \\
\text { acid soluble }\end{array}$ & 970 & 750 & 760 & 560 & 450 & $\mathbf{1}, 530$ \\
\hline Nucleic acid & 2,180 & 840 & 1,100 & 610 & 580 & 33,000 \\
\hline \multicolumn{7}{|c|}{ Fractionation of nucleic acid } \\
\hline Cytosine & 950 & 500 & 530 & 430 & 395 & 19,000 \\
\hline Uracil & 1,230 & 345 & 580 & 185 & 190 & 14,000 \\
\hline
\end{tabular}

Similar results were obtained for the incorporation of ${ }^{14} \mathrm{C}$ from Escherichia coli labelled with ${ }^{14} \mathrm{C}$-purines and having $62 \%$ of the ${ }^{14} \mathrm{C}$ present as adenine and $38 \%$ as guanine. Over $85 \%$ of ${ }^{14} \mathrm{C}$ in the protozoa was present in the cell pool, principally as xanthine and hypoxanthine, although three minor components were also present. Both ${ }^{14} \mathrm{C}$-adenine and ${ }^{14} \mathrm{C}$-guanine were found in the nucleic acid of the broken cell supernatant fluid and were present in the same proportions as in the initial $E$. coli. The incorporation of ${ }^{14} \mathrm{C}$ into the nucleic acid was decreased by $45 \%$ in the presence of $0.005 \mathrm{M}^{12} \mathrm{C}$-adenine and by $60 \%$ in the presence of $0.005 \mathrm{M}-{ }^{12} \mathrm{C}$-adenosine or ${ }^{12} \mathrm{C}$-adenosine $5^{\prime}$-monophosphate. With all three compounds over $80 \%$ of the decrease was the result of a decrease in the amount of ${ }^{14} \mathrm{C}$-adenine. 


\section{Source of ribose for protozoal nucleic acid}

On incubation of Entodinium caudatum with ${ }^{14} \mathrm{C}$-ribose, ${ }^{14} \mathrm{C}$ was incorporated progressively into the protozoa and after $5 \mathrm{hr} 50 \%$ was present in the cell pool as free ribose and $25 \%$ in the hot TCA-soluble fraction of the broken cell pellet as glucose. Only $5 \%$ was incorporated into the nucleic acid fraction of the broken cell supernatant fluid and it was not possible to identify ${ }^{14} \mathrm{C}$-ribose. Similarly, there was no incorporation of ${ }^{14} \mathrm{C}$ into nucleic acid ribose from ${ }^{14} \mathrm{C}$-glucose or ${ }^{14} \mathrm{C}$-starch. These results suggested that the protozoa probably obtained their nucleic acid ribose from engulfed bacteria and an attempt was made to prepare Escherichia coli labelled with ${ }^{14} \mathrm{C}$ ribose in its nucleic acid. Roberts et al. (1955) found that in $E$. coli free ribose was not utilized in the presence of glucose for nucleic acid synthesis, but that uridylic acid or uridine was incorporated intact into bacterial nucleic acid. In the present experiments this finding was confirmed when the concentration of ${ }^{14} \mathrm{C}$-uridine was greater than $0.0005 \mathrm{M}$. In the presence of tracer quantities of ${ }^{14} \mathrm{C}$-uridine, only the pyrimidines of the bacteria were labelled. In contrast with the results of Roberts et al. (I955), there was little incorporation of ${ }^{14} \mathrm{C}$ into the ribose of purine nucleotides but there was appreciable incorporation of ${ }^{14} \mathrm{C}$ into bacterial protein unless $0.005 \mathrm{M}$-L-aspartic acid was added to the growth medium. Entodinium caudatum was therefore allowed to engulf $E$. coli that had been grown on glucose + ammonia + salts medium $+0.0005 \mathrm{M}-\left[\mathrm{U}-{ }^{14} \mathrm{C}\right]-$ uridine $+0.005 \mathrm{M}$-L-aspartic acid. The ratio of ${ }^{14} \mathrm{C}$ in the pyrimidines to the ${ }^{14} \mathrm{C}$ in the pyrimidine nucleotides was measured for the bacterial and the protozoal nucleic acids in an attempt to determine whether the pyrimidine nucleosides were transferred intact into the protozoal nucleic acid. The free pyrimidines were liberated by hydrolysis in $72 \% \mathrm{HClO}_{4}$ and separated by chromatography in solvent $\mathrm{B}$. The pyrimidine nucleotides were liberated by hydrolysis in $\mathrm{N}-\mathrm{HCl}$ and separated from the purines and ribose by chromatography in solvent $\mathrm{D}$. In the bacteria the ratio of ${ }^{14} \mathrm{C}$ in pyrimidine nucleotides: ${ }^{14} \mathrm{C}$ in pyrimidines was $1500: 755=\mathrm{I} \cdot 99$, and in the protozoa it was $254 / \mathrm{I} 28=$ $\mathrm{I} \cdot 98$, which indicated that the pyrimidines were transferred at least at the degree of complexity of nucleosides. Free ribose had little (less than $10 \%$ ) effect on the incorporation of nucleosides into protozoal nucleic acid. In contrast, a mixture of ${ }^{12} \mathrm{C}$ uridine and ${ }^{12} \mathrm{C}$-cytidine (each $0.01 \mathrm{M}$ ) decreased the incorporation by $57 \%$, whereas a mixture of ${ }^{12} \mathrm{C}$-uracil $+{ }^{12} \mathrm{C}$-cytosine at the same concentration decreased it only by $36 \%$. These results support the suggestion that transfer from the bacteria and exchange with constituents in the medium occurs at the nucleoside or nucleotide level.

\section{Source of phosphate for protozoal nucleic acid}

As the above results did not distinguish between transfer of pyrimidines as nucleosides or nucleotides, Escherichia coli was prepared labelled with ${ }^{32} \mathrm{P}$ and ${ }^{14} \mathrm{C}$ and measurements made of the incorporation of both isotopes from bacterial into protozoal nucleic acid. These experiments were made in two ways, in both of which it was assumed that the ${ }^{14} \mathrm{C}$ incorporated into protozoal nucleic acid was derived solely from the bacterial nucleic acid. This assumption is probably justified, since from the results reported above and previously (Coleman, 1964, 1967a, b) there was no evidence for the formation of purines, pyrimidines or ribose from amino acids or carbohydrates. For the first type of experiment the $E$. coli was uniformly labelled with ${ }^{32} \mathrm{P}$ and ${ }^{14} \mathrm{C}$ by growth in the presence of ${ }^{32} \mathrm{P}$ inorganic phosphate $+[\mathrm{U}-14 \mathrm{C}]$ glucose. The ratio of 
${ }^{14} \mathrm{C}:{ }^{32} \mathrm{P}$ in the initial bacterial nucleic acid was 0.53 , whereas in the final protozoal nucleic acid after engulfment of the bacteria it was 0.84 . This suggested that only two molecules of phosphate were transferred for every three molecules of nucleoside. The ratio in the nucleic acid fraction of the broken cell pellet, which would contain any undigested bacteria, was 0.57 . To confirm this result the nucleic acid fractions were hydrolysed with $\mathrm{N}-\mathrm{HCl}$ and the pyrimidine nucleotides separated by two-dimensional paper chromatography in solvents $\mathrm{D}$ and $\mathrm{B}$. The ${ }^{14} \mathrm{C}:{ }^{32} \mathrm{P}$ ratios in the bacterial nucleic acid were 0.17 for cytidylic acid and 0.16 for uridylic acid, as compared with 0.24 for cytidylic acid and 0.18 for uridylic acid in the protozoal nucleic acid. As with the results on the whole nucleic acid fractions, these figures indicate that transfer from bacterial to protozoal nucleic acid occurred with a small loss of phosphate.

For the second experiment the bacteria were grown in the presence of $\left[8-{ }^{14} \mathrm{C}\right]$ adenine and ${ }^{32} \mathrm{P}$-inorganic phosphate and were therefore labelled in their nucleic acid with ${ }^{14} \mathrm{C}$-adenine, ${ }^{14} \mathrm{C}$-guanine and ${ }^{32} \mathrm{P}$. The nucleic acids were hydrolysed with $\mathrm{KOH}$ to liberate the ribonucleotides which were separated by chromatography in solvent $B$. The ${ }^{14} \mathrm{C}:{ }^{32} \mathrm{P}$ ratios in the adenylic acid from the bacteria and protozoa were 0.94 and 0.92 respectively; this showed that there was no loss of phosphate in the transfer from bacteria to protozoa. Although there were differences between the results obtained under the different experimental conditions they all showed that most of the transfer occurred at the nucleotide level.

\section{DISCUSSION}

Although many protozoa feed on bacteria there have been very few studies on the metabolism of bacterial components by these protozoa; the emphasis has usually been on the metabolism of axenic cultures. However, Berger \& Kimball (1964), Calkins \& Gunn (1967) and Albach, Shaffer \& Watson (1966) showed by using tritiated thymidine that bacterial DNA was used as a source of protozoal DNA in Paramecium aurelia, Tetrahymena pyriformis and Entamoeba histolytica, respectively. In contrast, Rosen, Rosen \& Horecker (1965) found that cell walls of Salmonella typhimurium were not digested by the cellular slime mould Polysphondylium pallidum. Unfortunately, since Entodinium caudatum cannot yet be grown monoxenically the results reported in the present paper and those published previously (Coleman, $1967 b$ ) have been obtained with non-multiplying suspensions. However they do represent one of the first attempts to investigate the fate of bacterial components, other than DNA, inside predatory protozoa. Entodinium caudatum has been particularly useful for this type of experiment, since one organism can engulf up to 200 bacteria/min. (Coleman, 1964) and can digest some bacteria to small molecular weight compounds in one hour.

The results obtained show that Entodinium caudatum can interconvert purines and pyrimidines to a limited extent although it is unable to interconvert amino acids (Coleman, I967a, b). The metabolic products of purine metabolism are consistent with their having been formed according to the following scheme:

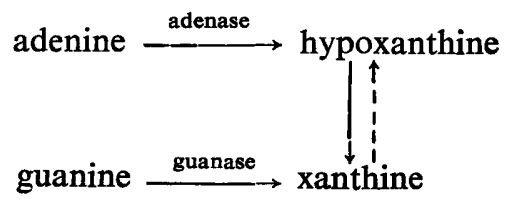


The oxidation of hypoxanthine to xanthine is the second example of an oxidative reaction which these strictly anaerobic protozoa can carry out; it was shown that certain amino acids were oxidatively deaminated (Coleman, 1967b).

The reductive metabolism of the pyrimidines occurs fairly widely among other organisms. Clostridium uracilicum reduces uracil to dihydrouracil which is then further degraded to $\beta$-ureidopropionic acid (Campbell, 1957). Zymobacterium oroticum reduces orotic acid to dihydroorotic acid (Lieberman \& Kornberg, 1953) and Fink et al. (1956) produced evidence that rats probably break pyrimidines down via dihydrouracil and dihydrothymine.

The finding that Entodinium caudatum incorporated free purines and pyrimidines into its nucleic acid shows that the protozoa possess the necessary enzymes to convert these compounds to nucleotides. However, the greater effectiveness of uridine and uridine $5^{\prime}$-monophosphate as compared with uracil, as competitors for uracil incorporation from bacterial into protozoal nucleic acid suggests that the protozoa can form nucleotides from nucleosides more easily than they can convert free pyrimidines into nucleosides. This is probably the result of a shortage of ribose inside the protozoa, since they cannot form it from other carbohydrates.

I thank Mr G. A. Embleton for inserting permanent rumen cannulas into the sheep used to provide rumen fluid for the routine maintenance of the protozoa, the members of the Sub-Department of Chemical Microbiology, Biochemistry Department, University of Cambridge, for their helpful advice and criticism, and Miss B. C. Hanzl for valuable technical assistance.

\section{REFERENCES}

Albach, R. A., Shaffer, J. G. \& Watson, R. H. (1966). Autoradiographic studies of $\mathrm{H}^{2}$ thymidine uptake in Entamoeba histolytica in CLG medium. J. Protozool. r3, 349.

Berger, J. D. \& KIMBaLl, R. F. (1964). Specific incorporation of precursors into DNA by feeding labelled bacteria to Paramecium aurelia. J. Protozool. Ir, 534.

CalkIns, J. \& GunN, G. (1967). The time of DNA synthesis during the inter-division growth cycle of Tetrahymena pyriformis fed on living bacteria. J. Protozool. r4, 210.

CAMPBELL, L. L. (1957). Reductive degradation of pyrimidines II. Mechanism of uracil degradation by Clostridium uracilicum. J. Bact. 73, 225.

Coleman, G. S. (1958). Maintenance of oligotrich protozoa from the sheep rumen in vitro. Nature, Lond. 182, 1104.

Colmman, G. S. (1960). Effect of penicillin on the maintenance of rumen oligotrich protozoa. Nature, Lond. $187,518$.

Coleman, G. S. (1962). The preparation and survival of almost bacteria-free suspensions of Entodinium caudatum. J. gen. Microbiol. 28, 27 I.

Coleman, G. S. (1964). The metabolism of Escherichia coli and other bacteria by Entodinium caudatum. J. gen. Microbiol. 37, 209.

Colzman, G. S. (1967a). The metabolism of free amino acids by washed suspensions of the rumen ciliate Entodinium caudatum. J. gen. Microbiol. 47, 433.

Coleman, G. S. $(1967 b)$. The metabolism of the amino acids of Escherichia coli and other bacteria by the rumen ciliate Entodinium caudatum. J. gen. Microbiol. 47, 449.

Davidson, J. N. \& Smellie, R. M. S. (1952). Phosphorus compounds in the cell 2. The separation by ionophoresis on paper of the constituent nucleotides of ribonucleic acid. Biochem. J. 52,594 .

Ellis, W. C. \& Pfander, W. H. (1965). Rumen microbial polynucleotide synthesis and its possible role in ruminant nitrogen utilization. Nature, Lond. 205, 974.

Fink, R. M., McGaughex, C., Cline, R. E. \& Fink, K. (1956). Metabolism of intermediate pyrimidine reduction products in vitro. J. biol. Chem. 218, I. 
LIEBERMAN, I. \& KornBerg, A. (1953). Enzymic synthesis and breakdown of a pyrimidine, orotic acid. I. Dihydro-orotic dehydrogenase. Biochim. biophys. Acta 12, 223.

LOOPER, D. C. \& STAllCuP, O. T. (1958). Release of ammonia from uric acid, urea and certain amino acids in the presence of rumen micro-organisms. J. Dairy Sci. 4x, 729.

Markham, R. \& Smтth, J. D. (1949). Chromatographic studies of nucleic acids. I. A technique for the identification and estimation of purine and pyrimidine bases, nucleosides and related substances. Biochem. J. 45, 294.

Roberts, R. B., Abelson, P. H., Cowie, D. E., Bolton, E. T. \& Britten, R. J. (1955). Studies on Biosynthesis in Escherichia coli. Publs Carnegie Instn, no. 607.

Rosen, O. M., Rosen, S. M. \& HoreCKER, B. L. (1965). Fate of the cell wall of Salmonella typhimurium upon ingestion by the cellular slime mold: Polysphondylium pallidum. Biochem. biophys. Res. Comm. 18, 270.

Scнмmі, G. (1955). Nucleases and enzymes attacking nucleic acid components. In The Nucleic Acids. Ed. by E. Chargaff and J. N. Davidson. Vol. I, p. 555. New York: Academic Press Inc.

Smith, J. D. \& MARKhAM, R. (1950). Chromatographic studies on nucleic acids. 2. The quantitative analysis of ribonucleic acids. Biochem. J. 46, 509.

Topps, J. H. \& Elliotr, R. C. (1965). Relationship between concentrations of ruminal nucleic acids and excretion of purine derivatives by sheep. Nature, Lond. 205, 498.

WyatT, G. R. (1951). The purine and pyrimidine composition of deoxypentose nucleic acids. Biochem. J. 48, 584 . 